Brian Williams

\section{Introduction: Maritime Archaeology in Ireland}

Despite living on an island situated in the North Atlantic Ocean, archaeologists in Ireland have, until relatively recently, worked almost exclusively on land. Within the last decade, governments in both jurisdictions in Ireland (Northern Ireland and the Republic of Ireland) have taken responsibility for the management of the island's maritime heritage and in doing so have released a wonderful flow of archaeological activity (Figure 1).
Initially, agency and archaeological attention turned to shipwrecks. The Environment and Heritage Service in Belfast and the Dúchas in Dublin created shipwreck inventories. Using documentary sources, evidence was found for some 13,000 shipping losses in Irish waters. The major obstacle to the documentary approach was an effective cutoff date at the early-18th century due to the nature of the sources. Although references to earlier shipping losses exist in the Irish Annals, for example, these wrecks are very difficult to locate as archaeological sites with any accuracy. Colin Breen, who did much of the work to amass the documentary evidence in both organizations, together with Wes Forsythe and Rory Quinn, reviews the material in his article on shipwreck analysis in Northern Ireland.

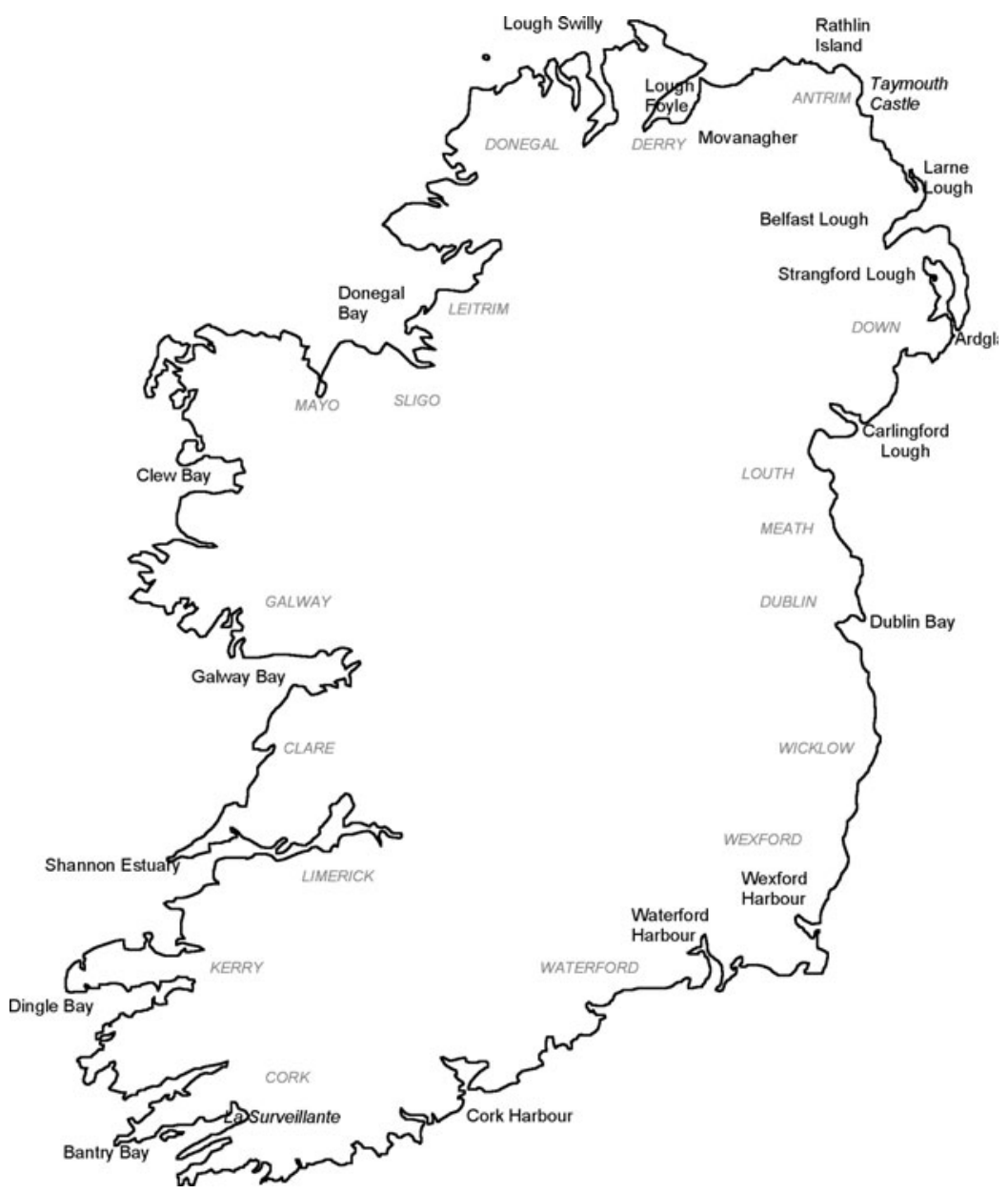

Figure 1. Ireland with places and sites mentioned in the text. (Drawing by Wes Forsythe, 2006.) 
As a first generation of professionals engaged in maritime archaeology, government inspectors such as the author have had to adapt to a steep learning curve in order to survive and take the subject forward. Gradually, as the subject emerged, it became evident that objective, scientific-survey methods might be the way to actually find evidence of shipwreck sites on the seabed. It was also thought that geophysical survey techniques might overcome the effective barrier to investigating earlier wrecks imposed by the nature of the documentary sources. Joseph Kelley, an American geomorphologist from the University of Maine, initiated the first hesitant steps towards seabed survey. Working in partnership with colleagues at the University of Ulster, he applied to what was then the Environment Service for some funding towards a seabed survey of Lough Foyle. While only a small sum of money was granted towards this project, it established that the method was suitable and created a relationship between the government and the University of Ulster. This work subsequently developed into the funding of a survey of the inshore waters of Northern Ireland undertaken by the University of Ulster. In his article on geophysics, Quinn outlines the techniques that have been used and proposes an alphanumeric system to integrate the information into a useful management system for government managers and researchers. The relationship between the University of Ulster and the government led to the creation of a joint initiative. In February 1999, the Centre for Maritime Archaeology (CMA) was opened.

CMA exists to undertake government tasks of recording and protecting maritime archaeology together with university functions of teaching and research. This combination has provided a great stimulus for activity in this new area of archaeological study, to the benefit of both organizations and to the subject itself. Master's students, destined to be the next generation of professionals, are being trained to a more appropriate level than earlier archaeologists who had to make the transfer from a background in land archaeology (for more information on CMA visit <http: //www.ulst.ac.uk/faculty/science/crg/cma.htm >).

Various levels of archaeological survey exist in the underwater environment. Examination of documentary sources, followed by geophysical survey, leads to a third stage-ground truthing by divers or remotely operated vehicles. CMA in collaboration with the Archaeological Diving Unit, formerly at the University of St Andrews, Scotland, started work at this third level. The final stage of recording is archaeological excavation. Claire Callaghan, Colin Breen, and Moira Ní Loingsigh report on excavating the 19thcentury fully rigged ship Taymouth Castle and demonstrate one of the great potential pitfalls of archaeological evidence. Based on the very extensive historical archive for this vessel, it is clear that the ship was engaged principally in the cotton trade, whereas the archaeological evidence indicated a trade in ceramics, bottled alcohol, and hardware items. This disparity is accounted for by the survival of material on the seabed. The principal cargo either floated off or rotted, leaving the more durable materials as evidence of the wrecking event. The lesson that this research provides should be borne in mind for many sites with less-detailed historical records.

Members of CMA led by Breen also undertook an investigation of the French Revolutionary vessel La Surveillante in Bantry Bay on Ireland's southwest coast. This work provided good information on the vessel itself, but it was part of the development of emergent thinking about maritime archaeology in Ireland in the mid- to late 1990s. Those involved realized the impact that the French Armada had on the built heritage on the land around Bantry Bay. Such was the alarm among the British in Ireland after the invasion attempt, that a system of naval fortification was established in the region. Forsythe has studied the fortifications in Bantry Bay since the Anglo-Norman period and presents it here.

The evident interaction between activities on land and sea led to a more holistic approach to the subject of maritime archaeology. Influenced by the writings of the Scandinavian archaeologist Christer Werterdahl, Irish maritime archaeologists have put into practice his concept of the maritime landscape. As the subject has unfolded in Ireland, there is an understanding that the maritime cultural landscape is a result of the interaction between the cultural and natural landscape in the maritime zone.

In Northern Ireland this viewpoint combined well with the Environment and Heritage Service initiative to undertake a pioneering survey 
of the archaeology in the intertidal zone in Strangford Lough. This sea lough (loch) was chosen because it was located in an area of well-known, high-quality land archaeology and it had a large area of seabed exposed between the tides. Undertaking this project raised a host of issues for those involved. In the first instance, there was no one in the area with any knowledge of intertidal archaeology. The decision was made to appoint a team of archaeologists experienced in conventional archaeological survey and to provide them with training in maritime safety. Archaeologists learned to dive, operate boats, use VHF radios and GPS, and understand mud safety. The Maritime and Coastguard Agency provided a great deal of this training for which we as archaeologists are very grateful

In the course of the survey, some 680 archaeological sites were recorded in the intertidal zone in a sea lough only 20 miles long and 3 miles wide. These ranged in date from 8,000 -year-old sites of submerged forests in the Mesolithic period to sites from postmedieval and modern times. Such was the quality of sites discovered that an impact was made on the archaeological community in Ireland, which came to realize the importance of the dynamic interface between land and sea and how it is reflected in the archaeological record.

One of the most important sites encountered in the survey of Strangford Lough was the two-phase tide mill found on the shore at Nendrum monastery. Excavations were started in an attempt to discover an interpretation for the structure. Tom McErlean's paper outlines the initial discovery that the site was a horizontal mill operated by the use of seawater delivered into the milldam on each high tide. Maritime archaeology is wetland archaeology. In the right circumstances, there can be outstanding preservation of organic materials. Excavation provided evidence for two mills dated from the many preserved oak structural timbers to between A.D. 619 and 788. Not only did this site contain the earliest known tide mill in the world, but also it shows the highly developed state of engineering in early Ireland.

There are many other aspects to the intertidal survey of Strangford Lough, and McErlean has selected a more recent activity in his study of the kelp industry. Although the site dates to the late-18th and early-19th centuries, little is known of the archaeological evidence for this activity among archaeologists and economic historians. In rural Ireland at that time, seaweed production was a major cash crop, second only in cash terms to cereal production. McErlean presents evidence for the sudden collapse of the industry. The economic impact on rural Ireland must have been very severe, particularly when combined with the second devastating blow to the same communities 20 years later during the famine that led to the loss of some $50 \%$ of the Irish population through death or emigration.

Defining the maritime cultural landscape can be elastic. In an island such as Ireland, which is said to be the 20th largest island in the world, one could argue that the entire country is a maritime landscape. Without the influence of the ocean and the warming effect of the Gulf Stream, life would be very different in a region located between 51 and 55 degrees north. A relatively mild and temperate climate has allowed successive generations to practice mixed farming. Access to the interior of the country by its rivers has provided a link to the sea, and few places on the island are more than 50 miles from the coast. Viewing the interior of the island as a maritime landscape allowed the editor to include Audrey Horning's paper, which describes plantation period settlement at Movanagher on the banks of the River Bann. Rory McNeary's article addresses the likely location of a whaling and shark fishery in Donegal Bay, blending maritime and shore-based evidence.

In Ireland, thinking on maritime archaeology has rapidly evolved from its initial position, which focused on shipwreck archaeology. Maritime archaeologists now include a much wider view and have a new perspective on the way archaeological evidence is interpreted as it sheds light on human activities and their relationship with the sea.

\section{BRIAN WiLLIAMS \\ Environment and Heritage Service \\ 5-33 Hill Street}

BeLFAST BT1 2LA

NORTHERN IRELAND, UK 